\title{
Exploring the Use of Youtube by Symphonic Orchestras as An Educational Platform During the Pandemic of Covid-19
}

\author{
Emine Serdaroglu \\ Dr., Bogazici University, Turkey
}

\begin{abstract}
The use of various digital platforms and social media applications has significantly been rising worldwide in the recent years. In 2020, during the covid-19 pandemic, many of these online platforms became important tools to support the distance learning especially for children, hence, underlying the need for authentic, safe, reliable, and easily accessible online resources of information. Before the pandemic, most of the renown symphonic orchestras have been offering to their community a wide range of educational music programs designed for various age groups from toddlers to adult listeners. Most of these orchestras also support official YouTube channels to self-promote and connect with a wider audience. YouTube is a popular social media application offering a rich selection of uploaded music video content which may be utilized as an easily accessible tool for music education. The aim of this research is to explore whether the symphonic orchestras share their expertise and educational content on their official YouTube channels to create safe and trustworthy resources designed particularly for children, thus supporting the online music education during the time of the covid-19 pandemic.
\end{abstract}

Keywords: music, online, education, orchestra, YouTube, technology, covid-19

\section{Introduction}

In modern society, people of all ages regularly use their smart phones, tablets, and computers. It is common to see a family dinner where children are watching videos using a tablet or to see people in coffee houses working on their laptops. Online applications became trendy and acceptable outlets allowing people to share their ideas and interact with one another (West, 2012). In recent years, the worldwide use of online platforms increased significantly. YouTube, visited each month by over 2 billion logged-in users, is certainly one of the most popular social media applications (YouTube Press, n.d.). Unlike some of the other social media platforms with age restrictions, YouTube is not only accessed by adults but also by children of various age groups. A research regarding the use of YouTube among parents of children between 16 to 36 months of age, indicates that most parents use YouTube, even with their toddlers (Ko, 2018).

Social media applications do not only change the way people communicate with one another, but they also transform conventional learning systems. They assist informal learning which is the act of learning outside of the formal school setting (Bull et al., 2008). In 2020, during the covid-19 pandemic, many of these online platforms became important tools to support the distance learning. YouTube emerges as one of the main sources for informal learning since it 
provides a broad selection of easily accessed videos. In previous years, numerous academic researches about the educational value and the possible applications of YouTube as part of K12 curriculum were conducted. In her doctoral dissertation, Rossini (2016) provides a comprehensive literature review taking into consideration teachers blending formal K-12 education structure with informal learning structures using social media tools. YouTube turns into a helpful tool also for teachers to create lesson plans, to find educational materials that support the concepts studied in the classroom and to better engage the students (Jones \& Cuthrell, 2011).

YouTube, with its extensive music content and endless repetition options helps music education as well (Cayari, 2011). In recent years, numerous studies were conducted to analyze the impact of YouTube on music. In some of these researches, the content listed under the category of music education is examined (Whitaker et al., 2014); the various ways virtual music communities use YouTube to enhance informal music learning are also studied (Kruse \& Veblern, 2012). Several of these researches concentrate on the role of YouTube regarding the musical learning experiences of younger children. It is suggested that audio and video recordings may be used as a tool to enhance child-centered music teaching curriculum, giving the young students the opportunity to re-listen and re-watch the activities previously done in classroom (Niland, 2009). In a research conducted among parents of toddlers, YouTube is perceived as beneficial in developing children's music skills (Ko, 2018). However, it is difficult to navigate among the vast number of available music videos. Many parents are concerned about the inappropriate material their younger children may be exposed to while watching YouTube unattended (Ko, 2018). In the early months of 2020 , most schools had to shut down across the world due to covid-19 pandemic and had to continue education using various forms of online learning. This sudden change in the educational system emphasized the need for authentic, safe, reliable, and easily accessible online educational resources designed especially for children.

Symphonic orchestras are prominent and historic music institutions. As the famous conductor Alan Gilbert (2015) states in the Guardian article, symphonic orchestras play a significant role as providers of music education. Before the onset of covid-19 pandemic, most of the renown symphonic orchestras have been offering to their community a wide range of educational music programs designed for various age groups from toddlers to adult listeners. Majority of these programs are designed to educate children of their community and to develop the love and appreciation of music from an earlier age. Most of these orchestras also support official YouTube channels to self-promote and connect with a wider audience. The purpose of this research is to explore whether the symphonic orchestras share their expertise and educational content on their official YouTube channels, to create safe and authentic online sources designed particularly for children, thus supporting the distant music education during covid19 pandemic.

\section{Methodology}

Google search is one of the first mediums people go to while they are in quest of information. Most parents and students looking for information supporting the music learning would most likely do their initial inquiries online. A similar approach is used to access the available online information. Firstly, Google searches are conducted to find symphonic orchestras from various countries offering educational programs to their community. The official websites of over forty internationally recognized symphony orchestras from Europe, the USA, Canada, China, 
and Austria, are reviewed considering the type of educational programs they offer to their community. The common approaches and exceptions among these programs are examined. During this research, only websites in English, French and Turkish languages are taken into consideration. Secondly, YouTube channels of these symphonic orchestras are explored, focusing mainly on the uploaded educational content, especially after the onset of covid-19 pandemic in March 2020. Among the large number of symphonic orchestras studied, the ones offering a wide and exemplary range of music education programs and having over 65.000 official YouTube channel subscribers are presented in this paper in alphabetical order.

\section{Berliner Philharmoniker (Berlin, Germany)}

Berliner Philharmoniker, dating back to 1882, is one the prominent orchestras of the world (History of Berliner Philharmoniker, n.d.). The orchestra offers a variety of educational activities including family and children's concerts, open rehearsals, choral projects, lectures as well as workshops for children and young musicians with the aim of making music accessible to as many people as possible in their community. These projects, initiated by Sir Simon Rattle and financially supported by Deutsche Bank, are designed to encourage people of all ages to engage in music and to learn to listen with refined ears (The Education Programme, n.d.). During 2020-2021 season, because of the ongoing covid-19 pandemic, Berliner Philharmonic announced only a limited number of live educational concerts on its web page. Nevertheless, 60 videos from selected educational projects are uploaded to "Media Library" located under the "Education" section of the official web page providing online educational resources. Berliner Philharmoniker offers another online service titled "Digital Concert Hall" (www.digitalconcerthall.com) where registered subscribers may listen and watch the most celebrated concerts of the orchestra digitally. Some of the previously recorded educational programs may be accessed on this platform free of charge and upcoming educational concerts may be accessed by subscribing to the channel.

The YouTube channel of Berliner Philharmoniker launched on January 19, 2009, with its 367.000 subscribers is an actively used online platform (Berliner Philharmoniker, n.d.). Extensive playlists of composers, conductors, soloists, concert seasons, popular uploads, and information about the orchestra's recordings as well as masterclasses are created for viewers. However, the rich educational programs offered by the orchestra are not shared on the official YouTube channel.

\section{Chicago Symphony Orchestra (Chicago, IL, USA)}

Founded in 1891, the renown Chicago Symphony Orchestra, reaches a wide audience with its seasonal concerts, national and international tours as well as best-selling recordings (About the CSO \& Symphony Center, n.d.). The Chicago Symphony Orchestra also provides several different educational programs for people of all ages and various backgrounds under the roof of the Negaunee Music Institute. "Once Upon a Symphony" intended for children between ages 3 to 5 and "CSO Family Matinee Series" for children 5 years and older are inspirational events designed as introductions to live music performances. Special concerts such as "Vienna Boys Choir" and "Merry, Merry Chicago!" are created for children 5 years of age or older. In addition to these projects, "School Concerts" are arranged to introduce K-8 grade students to symphonic music. Furthermore, open rehearsals are organized for students in high school (Negaunee Music Institute, n.d.). According to the announcement accessed in October 2020 in the "Tickets \& Events" section of the official web page (https://cso.org/20-21), Chicago Symphony Orchestra cancelled all scheduled programs between September 2020 and March 
2021 due to the ongoing covid-19 pandemic. Since live performances are cancelled, the orchestra created "CSO for Kids" section on their website, which aims to provide fun and educational remote learning sources for children of various ages (CSO for Kids: Remote Learning Resources, n.d.). The orchestra also provides music lovers with the opportunity to watch the performances via the online platform of "CSOtv" which may be accessed via https://cso.org/csotv/welcome/. In CSOtv, "CSO for Kids" section is created to provide free access to music related videos designed for children.

The Chicago Symphonic Orchestra's official YouTube channel was launched on April 11, 2007. The channel which has 122.000 subscribers, presents a rich selection of playlists including season trailers, interviews with guest artists, and with members of the symphony as well as clips of performances (Chicago Symphony Orchestra, n.d.). "Video Program Notes" presenting information about the pieces to be performed in the concerts and "Music NOW" about the acclaimed new-music series are two of the interesting playlists. "Virtual Recitals 2020/2021" and "Virtual Day of Music 2020" are some of the newer additions. "Negaunee Music Institute" playlist includes 36 uploaded videos providing an insight to the educational programs offered by the Institute. Family oriented Christmas programs are also advertised in short videos. Although some of the educational content is added to the YouTube channel, the extent of the educational children's programs is not yet presented.

\section{London Symphony Orchestra (London, UK)}

The London Symphony Orchestra, Britain's first independent and self-governing orchestra which gave its first concert in June 1904, is now considered as one of the leading orchestras of the world (Chronology: 1900s, n.d.). London Symphony Orchestra is also esteemed for its educational programs. "Concerts for Under-5s", "Family Concerts" suitable for ages 7 to 12, "Monday Morning Music Workshops" for babies and for children under the age of 5 as well as workshops for parents and babies from newborn to 6 months are counted among many educational activities. These interactive, creative, and fun activities are geared towards creating interest and early knowledge in children about music, orchestra, and instruments. LSO Discovery recently created an online resource providing a variety of music activities to support learning at home as well as at the school. These activities may be accessed on the "LSO Discovery" section of the official web page (About LSO Discovery, n.d.).

The YouTube channel of London Symphony Orchestra launched on May 19, 2006, with its 120.000 subscribers is one of the most popular orchestral YouTube channels (London Symphony Orchestra, n.d.). It offers clips of concerts, backstage interviews with the performers of the orchestra, conductors, and soloists as well as behind the scenes videos. Playlists include A-Level seminars, behind the scenes, favorites, and a variety of informative selections about the compositions. Masterclasses and video clips from the performances of modern compositions are also added. Listeners may also access live performances via the channel. "Coffee Sessions" playlist including the performances of orchestra members was added during the covid-19 lockdown in April 2020. The London Symphony Orchestra also plans to share some of the concerts on their YouTube channel during the Autumn season of 2020. Although new additions were done to the playlists since the beginning of the covid-19 pandemic, the extensive educational programs are not yet added to the YouTube channel. 


\section{New York Philharmonic Orchestra (New York, NY, USA)}

The New York Philharmonic founded in 1842 is the oldest symphony orchestra in the United States and is one of the most celebrated orchestras in the world (History, n.d.). The New York Philharmonic reaches a wide audience with live concerts and with broadcasts on television, radio and online. The orchestra also organizes numerous educational programs and activities for its community. "Young People's Concerts" incorporate a wide range of concerts designed for children of all ages. These concert series, with the addition of games, various activities, storytelling, and interactive encounters become delightful, fun, and educational experiences (Young People's Concerts, n.d.). Long term partnership of the New York Philharmonic Orchestra with various education institutions in New York and around the world is realized under the "Learning Communities" and "Partnerships" programs (Partnerships, n.d.). These programs help orchestra members share their knowledge and experience with teachers and students. New York Philharmonic recently added "NY Phil Learning @ Home” to their official web page to support remote online music learning at home (NY Phil Learning @ Home, n.d.). This section offers various online sources including concert and lessons to engage young audiences, families, and teachers.

The official YouTube channel of the New York Philharmonic Orchestra is activated on January 8,2008 . With 68.400 subscribers, it is an actively used channel providing a wide selection of playlists (New York Philharmonic, n.d.). Performances, rehearsals, seasons selections and tours are some of the popular playlists offered. Playlists dedicated to specific performers and composers are also presented. Until March 2020, only a few videos about the educational programs offered by the New York Philharmonic Orchestra were uploaded. Following the lockdown due to Covid-19 pandemic, new playlists such as "NY Phil Plays On" and "We Are NY Phil @ Home" were created. "Very Young People's Concerts @ Home" and "Young People's Concerts @Home” playlists which are designed specifically for children are also added to the channel.

\section{Royal Concertgebouw Orchestra (Amsterdam, Netherlands)}

The idea of building a new concert hall in Amsterdam was put on motion in 1881, the Concertgebouw was opened in April 1888 (History, n.d., Concertgebouw). Since then, the Royal Concertgebouw Orchestra continues to give concerts as one of the most celebrated orchestras in the world (Meet the Orchestra, n.d.). In the Concertgebouw, a wide variety of age specific concerts are offered for children. "Baby Concerts" for up to 16-month-old, "Toddler's Concerts" for children from 2 to 4 years old, "Beethoven's Birthday!" for 6 years old and older, "Be Bach" for 8 years and older audience are some of the exemplary concerts that are offered under "Family Concerts" (Family Concert, n.d.). During "RCO Meets Europe" project, the Royal Concertgebouw Orchestra performed side by side with 28 European youth orchestras and gave masterclasses in several countries sharing their experience and knowledge (RCO Meets Europe, n.d.). Live educational concerts are programmed for 2020-2021 season while taking the necessary health measures for covid-19.

The official YouTube channel, launched on March 29, 2007, supported by 65.900 subscribers, includes playlists presenting information about concert seasons, excerpts from concerts, behind the scenes videos and masterclasses (Concertgebouworkest, n.d.). "Complete Works" playlist gives access to recordings of the Royal Concertgebouw Orchestra. "Historic Footage" playlist including excerpts from historic concert recordings from 1930s to 1960s is also interesting. The playlist titled "Young" includes rehearsals and interviews with members of 
"Concertgebouworkest Young" which is the international youth orchestra formed of European musicians between the ages of 14 to 17 . However, consisted only of 28 videos, this playlist offers a limited insight. Short video selections from "RCO Meets Europe" project is also presented in the YouTube channel. A playlist title "Zwitsal Slaapliedjes" (Sleep Songs) including 6 videos consisting of performances of short classical compositions is added in July 2020 for children. However, the wide selections of concerts that are organized specifically for children of all ages are not uploaded to the channel yet.

\section{Discussion and Conclusion}

The potential of YouTube as an educational tool emerges as the subject of numerous studies. Many of these researches agree with J. Waldron (2013) who supports the idea that YouTube videos, promoting a participatory culture, fulfills a significant teaching role. YouTube may contain valuable material regarding music instruction, but it also contains an abundance of videos without any educational value. Since being able to choose the appropriate and highquality material among the large number of videos requires music literacy, it is difficult for most parents and students to get hold of the accurate and useful information (Spearman, 2000). Thus, it is important for trusted establishments, such as symphonic orchestras to provide high quality educational content on YouTube to provide easy and safe access to educational material.

Symphonic orchestras invest time, money, and knowhow to promote music education in their community. They put special emphasis on creating programs such as children's concerts, family concerts, school concerts, open-rehearsals and masterclasses which are specifically designed for children of various ages. These orchestras also invest in creating official YouTube channels to self-promote and to connect with a wider audience. These channels commonly include video selections from concerts, rehearsals, tours as well as season previews, interviews with orchestra members, conductors, guest performing artists and composers. Videos providing background information about the compositions performed during the concert season are also uploaded. However, videos containing their prolific and creative educational programs designed for children are not shared at all or briefly shared in the official YouTube channels.

Symphonic orchestras may take advantage of YouTube to boost the impact of their educational programs by reaching a much larger community. Music education programs of symphony orchestras are generally planned as community service and are not intended for financial profit. In this light, symphonic orchestras may upload previously recorded family and children's concerts to their YouTube channels. They may create various playlists intended for different age groups creating easy access for parents and children. They may also program live YouTube broadcasts re-creating some of the interactive programs previously put on stage in front of a live audience. Symphonic orchestras may significantly expand their community reach by using their official YouTube channels more effectively. Thus, they would emphasize their role as one of the significant contributors of music education by providing high quality, safe and well-constructed informative content for families, teachers, and children.

The recent covid-19 pandemic forced most of the K-12 schools to abruptly switch to remote education worldwide. This sudden change underlined the need for trustworthy and easily accessible online educational resources and urged many institutions to create these necessary online sources. Since March 2020, it is observed that symphonic orchestras also started to add new educational materials designed for children to their official web pages and to their official 
YouTube channels to support online music learning. It may be predicted that in near future YouTube will be used more often to support formal and informal music education. Thus, future research may be conducted about the most efficient, systematic, and inspiring ways of presenting the educational material already prepared by the symphonic orchestras in their official YouTube channels, expanding their sphere of influence and creating high quality, reliable, safe, authentic and easily accessible music education sources for children.

\section{References}

[1] About LSO Discovery (n.d.). London Symphony Orchestra. Retrieved March 14, 2020, from https://lso.co.uk/lso-discovery/about-lso-discovery.html.

[2] About the CSO \& Symphony Center (n.d.). Chicago Symphony Orchestra. Retrieved March 12, 2020, from https://cso.org/about/

[3] Berliner Philharmoniker (n.d.). YouTube. Retrieved October 20, 2020, from https://www.youtube.com/channel/UCtRkmSO4PrhJ4TzNOmFlwjw

[4] Bull, G., Thompson, A., Searson, M., Garofalo, J., Park, J., Young, C., \& Lee, J. (2008). Connecting informal and formal learning: Experiences in the age of participatory media. Contemporary Issues in Technology and Teacher Education, 8(2), 100-107.

[5] Cayari C. (2011). The YouTube effect: How YouTube has provided new ways to consume, create, and share music. International Journal of Education \& the Arts, 12 (6), 1-30. http://www.ijea.org/v12n6/

[6] Chicago Symphony Orchestra (n.d.). YouTube. Retrieved October 20, 2020, from https://www.youtube.com/channel/UCl2Sa1BW9yF55yjqwSLro6Q

[7] Chronology: 1900s (n.d.). London Symphony Orchestra. Retrieved March 14, 2020, from https://lso.co.uk/orchestra/history/chronology-alt/1900s.html

[8] Concertgebouworkest (n.d.). YouTube. Retrieved October 20, 2020, from https://www.youtube.com/user/rcolive/featured

[9] CSO for Kids: Remote Learning Resources (n.d.). Chicago Symphony Orchestra. Retrieved October 3, 2020, from https://cso.org/cso-from-home/cso-for-kids

[10] Family Concert (n.d.). Concertgebouw. Retrieved March 15,2020, from https://www.concertgebouw.nl/en/concerts-tickets/genre=Family+Concert

[11] Gilbert, A. (2015, April 15). Orchestras in the 21st Century - a new paradigm. The Guardian: International Edition. https://www.theguardian.com/music/2015/apr/15/alan-gilbert-orchestras-inthe-21st-century-a-new-paradigm

[12] History (n.d.). Concertgebouw. Retrieved March 15, 2020, from https://www.concertgebouw.nl/en/history

[13] History (n.d.). New York Philharmonic. Retrieved March 15, 2020, from https://nyphil.org/aboutus/history?clicklocation=main_nav_history.

[14] History of the Berliner Philharmoniker (n.d.). Berliner Philharmoniker. Retrieved March 12, 2020, from

[15] https://www.berliner-philharmoniker.de/en/history/beginning/\#event-establishment-of-a-neworchestra

[16] Jones, T. \& Cuthrell, K. (2011). YouTube: Educational potentials and pitfalls. Computers in the Schools, 28(1), 75-85. https://doi.org/10.1080/07380569.2011.553149

[17] Ko, M. Y. (2018). YouTube as an early childhood music education resource: Parental attitudes, beliefs, usages, and experiences [Doctoral dissertation, University of Missouri-Columbia]. ProQuest Dissertations \& Theses Global.

[18] https://search.proquest.com/docview/2278078269?accountid=9645 
[19] Kruse, N. B., \& Veblen, K. K. (2012). Music teaching and learning online: Considering YouTube instructional videos. Journal of Music, Technology \& Education, 5(1), 77-87.

https://doi.org/10.1386/jmte.5.1.77_1

[20] London Symphony Orchestra (n.d.). YouTube. Retrieved October 20, 2020, from https://www.youtube.com/channel/UCY1yTli-DaxPbNtLCnwAM1g

[21] Meet the Orchestra (n.d.). Concertgebouworkest. Retrieved March 15, 2020, from https://www.concertgebouworkest.nl/en/the-orchestra

[22] Negaunee Music Institute (n.d.). Chicago Symphony Orchestra. Retrieved March 12, 2020, from https://cso.org/institute/

[23] New York Philharmonic (n.d.). YouTube. Retrieved October 20, 2020, from https://www.youtube.com/user/NewYorkPhilharmonic

[24] Niland, A. (2009). The power of musical play: The value of play-based, child-centered curriculum in early childhood music education. General Music Today, 23(1), 17-21. https://doi.org/10.1177/1048371309335625

[25] NY Phil Learning @ Home (n.d.). New York Philharmonic. Retrieved on June 3, 2020, from https://nyphil.org/education/learning-at-home

[26] Partnerships (n.d.). New York Philharmonic. Retrieved March 15, 2020, from https://nyphil.org/education/partnerships

[27] RCO Meets Europe, n.d. Concertgebouworkest. Retrieved March 15, 2020, from https://www.concertgebouworkest.nl/europe

[28] Rossini, E.M. (2016). Administrators' Perceptions of Using Social Media as a Tool for Learning [Doctoral dissertation, Virginia Polytechnic Institute and State University]. VTechWorks. https://vtechworks.lib.vt.edu/handle/10919/82345

[29] Spearman, C. E. (2000). How will societal and technological changes affect the teaching of music? In C. K. Madsen (Ed.), Vision 2020: The Housewright Symposium on the Future of Music Education (pp. 153-184). Music Educators National Conference, Reston, VA

[30] The Education Programme of the Berliner Philharmoniker (n.d.). Berliner Philharmoniker. Retrieved March 12, 2020, from https://www.berliner-philharmoniker.de/en/education/

[31] Waldron, J. (2013). YouTube, fanvids, forums, vlogs, and blogs: Informal music learning in a convergent on-and offline music community. International Journal of Music Education, 31(1), 91105. https://doi.org/10.1177/0255761411434861

[32] West, D. M. (2012, April 24). How blogs, social media, and video games improve education. Governance Studies at Brookings. https://www.brookings.edu/research/how-blogs-social-mediaand-video-games-improve-education/

[33] Whitaker, J. A., Orman, E. K., \& Yarbrough, C. (2014). Characteristics of "music education" videos posted on YouTube. Update: Applications of Research in Music Education, 33(1), 49-56. https://doi.org/10.1177/8755123314540662

[34] Young People's Concerts (n.d.). New York Philharmonic. Retrieved March 15, 2020, from https://nyphil.org/education/young-peoples-concerts

[35] YouTube for press (n.d.). YouTube Press. Retrieved October 3, 2020, from https://www.youtube.com/int//en-GB/about/press/ 